\title{
PENERAPAN METODE PEMBELAJARAN TALKING STICK DALAM UPAYA PENINGKATAN HASIL BELAJAR POKOK BAHASAN IKLAN, SARANA KOMUNIKASI PADA KELAS VIII SMPN 1 SINGOSARI
}

\author{
Arief Nurcahyo \\ Sekolah Menengah Pertama Negeri 1 Singosari \\ Email: cahyonurarief@gmail.com
}

\begin{abstract}
The research aims are to know increasing learning outcome in advertisement subjects, means of communication on Indonesian Language course. This research used classroom research action method with two cycles. Subjects are 32 students grade VII SMPN 1 Singosari. Instruments were used like syllabus, lesson plan, formative test and observation sheets. Data analysis used quantitative descriptive technique. The results of research showed that mastery learning of student in cycle 1 , first meeting were $21,86 \%$ to be $62,5 \%$ on cycle 1 , second meeting and become $84,38 \%$ on cycle 2 . Talking Stick method were effective to increasing learning outcome of student in Indonesian Language subjects.
\end{abstract}

Key Words : talking stick, advertisement, indonesian language

\begin{abstract}
ABSTRAK
Tujuan penelitian ini untuk mengetahui peningkatan hasil belajar pokok bahasan iklan, sarana komunikasi pada mata pelajaran Bahasa Indonesia. Metode penelitian yang digunakan adalah Penelitian Tindakan Kelas dengan dua siklus. Subyek penelitian adalah 32 siswa kelas VII SMPN 1 Singosari. Instrumen yang digunakan adalah silabus, RPP, tes formatif dan lembar observasi. Analisis data dengan teknik deskriptif kuantitatif. Hasil penelitian menyebutkan bahwa ketuntasan belajar siswa pada siklus 1 pertemuan pertama sebesar 21,86\% menjadi 62,5\% pada siklus 1 pertemuan kedua dan menjadi $84.38 \%$ pada siklus dua. Metode Talking Stick efektif dalam meningkatkan hasil belajar siswa materi Bahasa Indonesia.
\end{abstract}

Kata Kunci: iklan, talking stick, bahasa indonesia

\section{PENDAHULUAN}

Undang-undang No. 20 Tahun

2003 tentang Sisdiknas pada pasal 3 menyatakan bahwa Pendidikan nasional berfungsi mengembangkan kemampuan dan membenuk watak serta peradaban bangsa yang bermartabat dalam rangka mencerdaskan kehidupan bangsa , bertujuan untuk berkembangnya potensi peserta didik agar menjadi manusia yang beriman dan bertakwa kepada Tuhan Yang Maha Esa, Berakhlak mulia, sehat, berilmu, cakap, kreatif, mandiri, dan menjadi warga negara yang demokratis serta bertanggung jawab.
Undang-undang No. 17 Tahun 2007 tentang Rencana Pembangunan Jangka Panjang Nasional tahun 2005-2025 menetapkan bahwa visi pembangunan nasional adalah untuk mewujudkan Indonesia yang Mandiri, Maju, Adil Dan Makmur. Visi tersebut diwujudkan melalui 8 (delapan) misi yang pada urutan pertamanya adalah Mewujudkan masyarakat berakhlak mulia, bermoral, beretika, berbudaya, dan beradab berdasarkan falsafah Pancasila. Dalam UU No. 20 Tahun 2003 tentang Sistem Pendidikan Nasional dinyatakan bahwa di setiap jenis, jalur dan jenjang pendidikan wajib memuat terdiri dari Pendidikan 
Bahasa, Pendidikan Agama, dan Pendidikan Kewarganegaraan.

Proses belajar merupakan inti dari proses pendidikan secara keseluruhan. Belajar diartikan sebagai proses perubahan tingkah laku dari individu berkat adanya interaksi antara individu dan individu dengan lingkungannya. Perubahan yang berarti bahwa seseorang setelah mengalami proses belajar, akan mengalami perubahan tingkah laku, baik aspek pengetahuan, keterampilan, maupun aspek sikap (Usman, 2003). Jadi Lingkungan sebagai dasar pengajaran adalah faktor kondisional yang mempengaruhi tingkah laku individu yang merupakan faktor belajar yang penting.

Secara umum bahasa memiliki peran sentral dalam perkembangan intelektual, sosial, dan emosional peserta didik. Bahasa merupakan penunjang keberhasilan peserta didik dalam mempelajari semua bidang studi. Pembelajaran bahasa diharapkan membantu peserta didik mengenal dirinya, budayanya, dan budaya orang lain. Selain itu, dengan bahasa peserta didik diharapkan mampu mengemukakan gagasan dan perasaan, berpartisipasi dalam masyarakat yang menggunakan bahasa tersebut, dan menemukan serta menggunakan kemampuan analitis dan imajinatif yang ada dalam dirinya.

Bahasa Indonesia mempunyai kedudukan yang sangat penting dalam kehidupan bangsa dan negara, Indonesia. Pentingnya peranan bahasa itu bersumber pada kedudukan bahasa, Indonesia sebagai bahasa nasional dan sebagai bahasa resmi Negara. Hal ini mempunyai fungsi sebagai alat untuk menjalankan admistrasi Negara, sebagai alat pemersatu berbagai masyarakat yang berbeda-beda latar belakang sosial budaya dan bahasanya, dan media untuk mengkomunikasikan kebudayaan nasional.

Pada tingkat pendidikan dasar (VII-IX) kompetensi yang diharapkan muncul dalam pelajaran Bahasa Indonesia adalah 1) Memiliki perilaku jujur, percaya diri, tanggung jawab, kreatif, peduli, santun dalam merespons berbagai hal secara pribadi, 2) Mengenal konteks sosial, satuan kebahasaan, serta unsur paralinguistik dalam penyajian teks, 3) Mengenal bentuk dan ciri teks dalam genre cerita, faktual, dan tanggapan, 4) Memahami teks dalam genre cerita, faktual, dan tanggapan, 5) Mengklasifikasi teks dalam genre cerita, faktual, dan tanggapan, 6) Menemukan makna teks dalam genre cerita, faktual, dan tanggapan, 7) Menyajikan teks dalam genre cerita, faktual, dan tanggapan secara lisan dan tulis, 8) Memiliki perilaku jujur, percaya diri, kreatif, peduli serta santun dalam menangani dan memberikan berbagai hal, 9) Mengenal konteks budaya dan konteks sosial, satuan kebahasaan, serta unsur paralinguistik dalam penyajian teks, 10) Mengenal bentuk dan ciri teks dalam genre faktual, tanggapan, dan cerita, 11) Memahami teks dalam genre faktual, tanggapan, dan cerita, 12) Mengklasifikasi teks dalam genre faktual, tanggapan, dan cerita, 13) Menemukan makna teks dalam genre faktual, tanggapan, dan cerita, 14) Menyajikan teks dalam genre faktual, tanggapan, dan cerita secara lisan dan tulis.

Ruang Lingkup Materi Bahasa Indonesia Pada tingkat pendidikan dasar (VII-IX) adalah sebagai berikut Satuan bahasa pembentuk teks: bunyi bahasa, fonem, morfem, kata, kelas kata, frasa, klausa, Penanda kebahasaan dalam teks. Paralinguistik (lafal, kelantangan, intonasi, tempo, gestur, dan mimik). Struktur teks genre cerita (teks eksemplum), genre faktual (teks rekaman percobaan) dan genre tanggapan (teks tantangan, tanggapan kritis). Konteks budaya, norma, serta konteks sosial yang melatarbelakangi lahirnya jenis teks.

Pendidikan merupakan kegiatan yang universal dalam kehidupan manusia, dengan pendidikan manusia berusaha mengembangkan potensi yang dimilikinya, mengubah tingkah laku ke 
arah yang lebih baik. Maju mundurnya suatu bangsa banyak ditentukan oleh maju mundurnya suatu pendidikan di Negara tersebut. Kualitas pendidikan yang tinggi diperlukan untuk menciptakan kehidupan yang cerdas, damai, terbuka, demokratis dan mampu bersaing (Winaputra, 2011).

Karakteritik aktivititas belajar sebagaimana tercantum dalam lampiran peraturan menteri pendidikan dan kebudayaan nomor 22 tahun 2016 tentang standar proses pendidikan dasar dan menengah domain pengetahuan ini memiliki perbedaan dan kesamaan dengan aktivitas belajar dalam domain keterampilan. Untuk memperkuat pendekatan saintifik, tematik terpadu, dan tematik sangat disarankan untuk menerapkan belajar berbasis penyingkapan/penelitian

(discovery/inquiry learning). Untuk mendorong peserta didik menghasilkan karya kreatif dan kontekstual, baik individual maupun kelompok, disarankan yang menghasilkan karya berbasis pemecahan masalah (project based learning).

Membelajarkan bahasa Indonesia berbeda dengan membelajarkan kompetensi nonbahasa. Perbedaannya adalah membelajarkann yang nonbahasa kecenderungannya siswa belum menguasai materi tersebut. Sebaliknya mengajarkan bahasa Indonesia menghadapi peserta didik yang sudah dapat berbahasa Indonesia. Sangat lazim terdengar ucapan "untuk apa belajar bahasa Indonesia?" ucapan ini dapat menyebabkan kurang bersemangatnya peserta didik untuk belajar bahasa Indonesia.

Tujuan pembelajaran bahasa Indonesia adalah membantu peserta didik mengembangkan kemampuan berkomunikasi, baik secara lisan maupun secara tulis (Purwo, 1997: 13). Kemampuan berkomunikasi yang mendasar ialah kemampuan menangkap makna dan pesan, termasuk menafsirkan dan menilai, serta kemampuan untuk mengekspresikan diri dengan bahasa.

Tujuan yang hendak dicapai atau dituju dalam mata pelajaran Bahasa Indonesia adalah sebagai berikut:

1. Berkomunikasi secara efektif dan efisien sesuai dengan etika yang berlaku, baik secara lisan maupun tulis

2. Menghargai dan bangga menggunakan bahasa Indonesia sebagai bahasa persatuan dan bahasa negara

3. Memahami bahasa Indonesia dan menggunakannya dengan tepat dan kreatif untuk berbagai tujuan

4. Menggunakan bahasa Indonesia untuk meningkatkan kemampuan intelektual, serta kematangan emosional dan sosial

5. Menikmati dan memanfaatkan karya sastra untuk memperluas wawasan, memperhalus budi pekerti, serta meningkatkan pengetahuan dan kemampuan berbahasa

6. Menghargai dan membanggakan sastra Indonesia sebagai khazanah budaya dan intelektual manusia Indonesia.

7. Salah satu materi pelajaran Bahasa Indonesia yang penting karena berkaitan dengan sebuah pesan yang disampaikan pada Bab II tentang iklan, sarana komunikasi. Pada bab ini akan diberikan beberapa gambaran bahwa dalam kehidupan sosial komunikasi menjadi hal yang sangat penting dalam pergaulan sosial di masyarakat.

Penelitian tindakan kelas yang diajukan ini mempunyai judul Penerapan Metode Pembelajaran Talking Stick dalam Upaya Peningkatan Hasil Belajar Pokok Bahasan Iklan, sarana Komunikasi Pada Kelas VIII SMPN 1 Singosari.

\section{METODE PENELITIAN}

Penelitian ini merupakan jenis Penelitian Tindakan Kelas (PTK) merupakan penelitian tindakan yang 
dilakukan dengan tujuan untuk memperbaiki praktik pembelajaran di kelas. Subyek dari penelitian ini adalah siswa siswi kelas VIII di SMPN Singosari yang berjumlah 32 siswa. Waktu penelitan dilaksanakan bulan September 2017 dengan durasi 3 kali pertemuan selama $2 \mathrm{x}$ 40 menit. Penelitian ini dilaksanakan dalam dua siklus.

Instrumen penelitian yang disusun meliputi silabus dan RPP pokok bahasan Iklan, Sarana Komunikasi; tes formatif setiap pertemuan; serta lembar observasi saat pembelajaran berlangsung. Prosedur penelitian dalam penelitian ini digambarkan sebagai berikut:

\section{Siklus I}

\section{a. Perencanaan}

Penelitian tindakan kelas ini dilakukan secara berkelanjutan. Dalam penelitian tindakan kelas ini diharapkan kita dapat mengetahui efektifitas dari penggunaan metode pembelajaran talking stick dalam mengatasi aktivitas belajar siswa. Penelitian ini hanya membatasi dua siklus yang dilaksanakan dengan harapan akan terlihat perbaikan yang dilaksanakan dengan menggunakan metode talking stick. Adapun langkah atau prosedurnya adalah sebagai berikut :

1. Perencanaan meliputi penyusunan silabus, RPP, penetapan materi yang akan dterapkan dengan menggunakan model pembelajaran kooperatif tipe talking stick pada materi menepis lupa jasa inspirator bangsa

2. Persiapan media yang akan digunakan dalam pembelajaran

3. Persiapan lembar observasi untuk setiap berlangsungnya pembelajaran Bahasa Indonesia.

4. Persiapan soal test yang akan diberikan pada setiap siklus.

5. Pelaksanaan tindakan, tahap ini guru akan melakukan pembelajaran aktif tipe talking stick yang telah direncanakan sesuai dengan panduan yang telah dibuat dan tertuang dalam RPP dan disesuaikan dengan kegiatan pembelajaran. Pada siklus I pokok bahasan yang digunakan adalah menentukan unsur-unsur iklan, slogan dan poster.

Tahap observasi dilakukan dengan mengamati proses pembelajaran secara kolaboratif dengan pengamat terhadap kegiatan yang dilakukan siswa dan guru. Kegiatan ini dilakukan selama proses pembelajaran berlangsung dengan menggunakan lembar observasi yang telah disiapkan sebelumnya. Tahap refleksi peneliti melakukan penilaian dan pengkajian terhadap hasil evaluasi data kaitannya dengan indikator kinerja Siklus I. Refleksi untuk tahap ini dilakukan dengan cara mengumpulkan data dari hasil observasi dan catatan lapangan, kemudian didiskusikan antara guru dengan pengamat, kemudian merumuskan perencanaan untuk siklus kedua. Evaluasi data penilaian berbentuk tes formatif untuk menilai hasil atau dampak metode talking stick yang telah dilaksanakan. Pada tes formatif ini bila belum diperoleh atau belum mencapai seperti dengan indikator pencapaian maka perlu dilakukan tindakan lanjutan pada siklus II dengan pokok bahasan atau materi yang berbeda.

Siklus II

Sesuai hasil refleksi siklus I maka perencanaan siklus II meliputi kegiatan sebagai berikut :

1. Identifikasi masalah pada siklus I dan penetapan alternatif pemecahan masalah, menentukan pokok bahasan menyimpulkan pesan dan informasi dalam iklan.

2. Membuat Rencana Pelaksanaan Pembelajaran (RPP) dengan metode talking stick.

3. Mengembangkan skenario pembelajaran, menyiapkan sumber belajar, mengembangkan format evaluasi pembelajaran.

Pelaksanaan tindakan tindakan dilakukan dengan memperbaiki tindakan sesuai dengan skenario pembelajaran yang telah disempurnakan. Berdasarkan hasil refleksi pada siklus I, dalam membentuk 
kelompok belajar, siswa dibagi menjadi kelompok yang lebih banyak dari siklus I sehingga anggota kelompok lebih sedikit, memantau perkembangan membuat talking stick dalam pembelajaran.

Tahap observasi dilakukan dengan mengamati proses pembelajaran (kegiatan siswa dan guru). Observasi diarahkan pada poin-poin pedoman observasi yang telah disiapkan oleh peneliti. Dilanjutkan dalam tahap refleksi, peneliti melakukan penilaian dan pengkajian terhadap hasil evaluasi data kaitannya dengan indikator kinerja Siklus II. Penilaian formatif dilakukan untuk menilai hasil atau dampak metode talking stick yang akan telah dilaksanakan pada siklus II.

Indikator keberhasilan pada hasil belajar ini adalah 80\% siswa mencapai nilai di atas KKM. Nilai KKM pada pelajaran Bahasa Indonesia di SMPN 1 Singosari sebesar 78.

Prosedur penelitian dalam penelitian ini digambarkan sebagai berikut :

Siklus I, Perencanaan

Pada tahap ini guru menyusun perencanaan pembelajaran Silabus dan RPP sesuai dengan langkah-langkah dalam model pembelajaran kooperatif tipe talking stick, kemudian guru membuat lembaran observasi untuk guru dan siswa. Tahap pelaksanaan tindakan dilakukan oleh guru dalam 2 kali pertemuan dengan menggunakan kompetensi inti memahami pengetahuan (faktual, konseptual, dan procedural) berdasarkan rasa ingin tahunya tentang ilmu pengetahuan, teknologi, seni, budaya terkait fenomena dan kejadian tampak mata.

1) Pertemuan Pertama

Pelaksanaan tindakan ini diawali dengan guru masuk kelas sambil memberikan salam kepada siswa kemudian guru mengabsensi siswa. Setelah itu guru membuka pelajaran dengan menyampaikan standar kompetensi, kompetensi dasar dan tujuan pembelajaran yang ingin dicapai tanpa membuat apersepsi atau membuka pemahaman siswa tentang materi yang akan diajarkan serta memberikan motivasi dan dorongan kepada siswa. Kemudian guru memberikan penjelasan tentang pengertian dan fungsi iklan, slogan dan poster ada beberapa siswa yang tidak memperhatikan dan asik berbicara dengan teman, namun guru tidak menghiraukannya. Setelah memberikan penjelasan, guru kemudian membagikan siswa kedalam 7 kelompok. Kelompok ini dibentuk berdasarkan nilai tes awal.

Setiap kelompok dibagikan bahan ajar yang sudah disiapkan oleh guru untuk kemudian didiskusikan dalam kelompok. Waktu yang diberikan kepada masingmasing kelompok untuk berdiskusi, membaca dan mempelajari materi yaitu 15 menit. Dalam kegiatan berdiskusi guru "disengaja" kurang mengontrol dan kurang memberikan bimbingan kepada kelompok dalam berdiskusi sehingga kebanyakan siswa tidak mempelajari materi yang sudah dibagikan.

Setelah 15 menit, guru kemudian memersilahkan kelompok kelompok untuk memersentasekan laporannya yang dimulai dari kelompok 1 kemudian 2, 3, 4 dan 5, 6, 7. Guru mempersilahkan siswa untuk menutup buku kemudian guru mengambil tongkat yang sudah disiapkan, setelah itu guru melakukan kegiatan Tanya jawab dengan menggunakan bantuan tongkat, guru memberikan tongkat kepada siswa dan siswa yang memegang tongkat berhak menjawab pertanyaan dari guru. Setelah menjawab pertanyaan dari guru tongkat kemudian diberikan kepada kelompok lainnya begitu seterusnya sampai sebagian besar siswa mendapatkan bagiannya.

Saat melakukan kegiatan tanya jawab, ada beberapa siswa yang masih kaku, takut dan kelihatan gugup karena mereka belum terbiasa dan baru pertama kali diperkenalkan dengan metode pembelajaran kooperatif tipe talking sitick. Setelah melakukan kegiatan tanya jawab guru menutup pelajaran dengan merangkum materi yang sudah dipelajari bersama siswa. 


\section{2) Pertemuan Kedua}

Seperti biasanya guru masuk kelas sambil memberikan salam kepada siswa kemudian guru mengabsensi siswa. Setelah mengabsensi siswa guru memerintahkan siswa untuk duduk di dalam masing-masing kelompok yang sudah dibentuk pada pertemuan pertama. Setelah siswa duduk di kelompoknya masing-masing, guru bersama peneliti membagikan bahan belajar kepada siswa. Kemudian guru membuka pelajaran dengan menyampaikan standar kompetensi, kompetensi dasar dan tujuan pembelajaran yang ingin dicapai tanpa membuat apersepsi atau membuka pemahaman siswa tentang materi yang akan diajarkan serta memberikan motivasi dan dorongan kepada siswa.

Guru memberikan penjelasan tentang materi yang akan dipelajari yaitu tokoh-tokoh yang mengemukakan ide maksud suatu iklan. Guru memberikan waktu kepada siswa untuk membaca dan berdiskusi dengan teman-temanya dalam kelompok. Waktu yang diberikan yaitu 15 menit. Dalam kegiatan diskusi siswa membaca dan mempelajari materi yang sudah dibagikan oleh guru dan membuat hasil belajar kelompoknya. Mereka saling bertukar pendapat dan menayakan hal-hal yang kurang dimengerti sampai pada waktu yang sudah ditentukan, siswa dipersilahkan untuk mempersentasekan laporannya, kemudian guru memerintahkan siswa untuk menutup buku atau bahan ajar yang sudah dipelajari, guru mengambil tongkat yang sudah disiapkan dan melakukan kegiatan tanya jawab. Dalam melakukan kegiatan tanya jawab, tongkat diberikan kepada siswa, kemudian guru memberikan pertannyaan kepada siswa, dan siswa yang memegang tongat berhak menjawab pertanyaan dari guru. Kemudian tongkat diberikan kepada kelompok lainnya dan siswa yang memegang tongkat berhak menjawab pertanyaan dari guru. Begitu seterusnya sampai sebagian besar siswa mendapatkan bagiannya. Setelah selesai melakukan kegiatan tanya jawab guru kemudian menutup pelajaran, guru bersama siswa merangkum materi yang sudah dipelajari. Guru mengadakan evaluasi tes akhir. Evaluasi dilakukan untuk mengetahui tingkat pemahaman siswa terhadap materi yang sudah dipelajari. Dalam kegiatan evaluasi tes akhir siklus I guru dibantu rekannya bertugas untuk mengontrol proses jalannya evaluasi tes akhir.

\section{Siklus II}

Pada proses ini diawali dengan evaluasi menyeluruh terhadap kelemahan yang ditemukan pada siklus I, maka perlu diadakan perbaikan pada siklus II. Pada tahap perencanaan, guru membuat Rencana Pelaksanaan Pembelajaran (RPP) sesuai dengan langkah-langkah yang ada pada metode pembelajaran kooperatif tipe talking stick.

Seperti biasanya guru masuk kelas sambil memberikan salam kepada siswa, disusul dengan mengabsensi siswa. Guru memberikan informasi kepada siswa bahwa hari ini akan diadakan evaluasi tes akhir kemudian melanjutkan materi yang akan dipelajari. Guru membentuk kelompok, setelah itu guru bersama rekan membagikan bahan belajar kepada siswa.

Kemudian guru memberikan telaah pola, struktur, dan kaidah kebahsaan iklan. Setelah guru memberikan penjelasan, siswa diminta untuk membaca dan berdiskusi dengan teman-temanya dalam kelompok. Waktu yang diberikan yaitu 15 menit. Dalam kegiatan diskusi siswa membaca dan mempelajari materi yang sudah dibagikan oleh guru dan membuat hasil belajar kelompok.

Guru bersama membagikan bahan belajar kepada siswa, setelah itu guru menyampaikan kepada siswa bahwa tolong perhatikan apa yang akan di jelaskan agar siswa dapat mengerti penjelasan dari guru, dalam hal ini guru memberikan motivasi kepada siswa. 
Kemudian guru memberikan penjelasan tentang pola penyajian iklan, struktur teks iklan, serta kaidah kebahasaan iklan.

Setelah guru memberikan penjelasan, siswa diminta untuk membaca dan berdiskusi dengan teman-temanya dalam kelompok. Waktu yang diberikan untuk berdiskusi yaitu 15 menit. Dalam kegiatan diskusi siswa membaca dan mempelajari materi yang sudah dibagikan oleh guru dan membuat hasil belajar kelompoknya. Mereka saling bertukar pendapat dan menayakan hal-hal yang kurang dimengerti, sementara guru mengontrol dan memberikan bimbingan pada tiap-tiap kelompok sampai pada waktu yang sudah ditentukan.

Guru mempersilakan siswa untuk menjabarkan hasil kerja kelompoknya melalui laporannya, setelah tiap-tiap kelompok mempresentasekan laporannya siswa diminta untuk menutup buku atau bahan ajar yang sudah dipelajari. Guru mengambil tongkat yang sudah disiapkan dan melakukan kegiatan tanya jawab. Dalam melakukan kegiatan Tanya jawab, tongkat diberikan kepada siswa, setelah itu guru memberikan pertannyaan kepada siswa, siswa yang memegang tongkat menjawab pertanyaan dari guru. setelah itu tongkat diberikan kepada kelompok lainnya dan siswa yang memegang tongkat berhak menjawab pertanyaan dari guru. begitu seterusnya sampai sebagian besar siswa mendapatkan bagiannya.

Setelah melakukan kegiatan tanya jawab guru kemudian menutup pelajaran. Guru memberikan kesempatan kepada siswa untuk menayakan materi yang belum dipahami. Ada beberapa siswa yang mengajukan pertanyaan, kemudian guru menjelaskannya. Setelah menjawab pertanyaan dari siswa, guru bersama siswa merangkumkan materi yang sudah dipelajari. kemudian guru mengadakan evaluasi tes akhir siklus.

Teknik analisis data dilakukan pada data tes formatif untuk menilai hasil atau dampak metode talking stick yang akan telah dilaksanakan pada siklus II.

Indikator keberhasilan pada hasil belajar ini adalah $80 \%$ siswa mencapai nilai di atas KKM. Nilai KKM pada pelajaran Bahasa Indonesia di SMPN 1 Singosari sebesar 78. Analisis data kuantitatif yang dilakukan sebagai berikut:

1. Menentukan skor nilai siswa

Keterangan:

$$
N=\frac{B}{S} \times 100
$$

$\mathrm{N}=$ Nilai siswa

$\mathrm{B}=$ Banyaknya jawaban benar siswa

$\mathrm{S}=$ Skor maksimal

2. Menghitung ketuntasan belajar secara klasikal

Keterangan:

$$
P=\frac{R}{T} \times 100
$$

$\mathrm{P}=$ Prosentase kelulusan

$\mathrm{R}=$ Jumlah siswa yang melebihi 75

$\mathrm{T}=$ Jumlah siswa

\section{HASIL PENELITAN DAN PEMBAHASAN \\ Berdasarkan data yang} dikumpulkan melalui hasil tes awal, dapat diketahui bahwa tingkat pemahaman siswa dalam menyelesaikan soal tes pada mata pelajaran Bahasa Indonesia dengan materi unsur-unsur iklan, slogan dan poster menunjukkan hasil yang kurang atau bahkan tidak menggembirakan, hal ini dapat dilihat pada tabel berikut.

Tabel 1. Persentase Nilai Hasil Belajar Tes Awal

\begin{tabular}{|c|c|c|c|}
\hline $\begin{array}{c}\text { Tabel } \\
\text { Penguasaan }\end{array}$ & Frekuensi & $\begin{array}{c}\text { Persentase } \\
(\mathbf{\%})\end{array}$ & Kategori \\
\hline $78 \%-100 \%$, & 7 & 21.86 & $\begin{array}{c}\text { Sangat } \\
\text { Tinggi }\end{array}$ \\
\hline $56 \%-77 \%$ & 22 & 68,75 & Tinggi \\
\hline $40 \%-55 \%$ & 3 & 9.37 & Sedang \\
\hline $0 \%-39 \%$ & 0 & 0 & Rendah \\
\hline Jumlah & $\mathbf{3 2}$ & $\mathbf{1 0 0}$ & \\
\hline \multicolumn{2}{|r|}{ Berdasarkan tabel tersebu } \\
\hline
\end{tabular}

menunjukkan bahwa hasil belajar pada tes awal menunjukkan persentase sebagai berikut; yang mencapai rentang nilai 78 - 
100 sejumlah 7 siswa dengan persentase $21,86 \%$, kemudian siswa yang memperoleh nilai dalam kisaran 56-77 sejumlah 22 siswa dengan persentase $68,75 \%$, kemuidan 3 siswa memperoleh nilai pada kisaran 40-55 sejumlah 9.37\%, rata-rata kelas adalah 67.63. Dari hasil di atas menunjukkan bahwa sebagian besar siswa belum memenuhi Kriteria Ketuntasan Minimum (KKM).

Tabel 2, Persentase Nilai Hasil Belajar Tes Kedua Siklus 1

\begin{tabular}{|c|c|c|c|}
\hline $\begin{array}{c}\text { Tabel } \\
\text { Penguasaan }\end{array}$ & Frekuensi & $\begin{array}{c}\text { Persentase } \\
(\mathbf{\%})\end{array}$ & Kategori \\
\hline $78 \%-100 \%$, & 20 & 62.5 & $\begin{array}{c}\text { Sangat } \\
\text { Tinggi }\end{array}$ \\
\hline $56 \%-77 \%$ & 12 & 37.5 & Tinggi \\
\hline $40 \%-55 \%$ & 0 & 0 & Sedang \\
\hline $0 \%-39 \%$ & 0 & 0 & Rendah \\
\hline Jumlah & 32 & 100 & \\
\hline
\end{tabular}

Berdasarkan tabel tersebut menunjukkan bahwa hasil belajar pada tes pertemuan kedua siklus I menunjukkan peningkatan. Peningkatan pertama adalah nilai rata-rata kelas dari sebelumnya adalah 67.63. kemudian pada pertemuan kedua siklus pertama meningkat menjadi 76.94. Selanjutnya pada rentang nilai $78-$ 100 memiliki persentase $21,86 \%$ meningkat menjadi $62.5 \%$.

Kemudian siswa yang memperoleh nilai dalam kisaran 56-75 sebelumnya sejumlah 19 siswa dengan persentase $68,75 \%$ pada pertemuan kedua menurun menjadi $37.5 \%$ dengan penurunan siswa dari 22 menjadi 12 siswa. Kemudian siswa yang memperoleh nilai pada kisaran 40-55 sejumlah 3 siswa atau $9.37 \%$ saat pertemuan pertama, ketika pertemuan kedua jumlahnya tidak ada atau tidak ada siswa yang memperoleh rentang nilai terendah tersebut. Peningkatan ini tentu menggembirakan, tetapi masih belum memuaskan hal ini dikarenakan siswa yang tidak mencapai KKM yang cukup banyak sehingga diperlukan lagi siklus kedua
Siklus pertama dengan gambaran hasil yang diperoleh siswa dalam pelajaran Bahasa Indonesia dengan materi menentukan iklan, sarana, komunikasi dan menyimpulkan pesan dan informasi iklan, akan dilanjutkan menuju siklus kedua, dan diharapkan pada siklus kedua akan tercapai tujuan sebagaian besar peserta didik atau 80 persen peserta didik atau siswa mencapai KKM yaitu minimal 78 . Selengkapnya dapat dilihat melalui tabel berikut ini.

\section{Tabel 3 Persentase Nilai Hasil Belajar Tes} Siklus 2

\begin{tabular}{|c|c|c|c|}
\hline $\begin{array}{c}\text { Tabel } \\
\text { Penguasaan }\end{array}$ & Frekuensi & $\begin{array}{c}\text { Persentase } \\
(\%)\end{array}$ & Kategori \\
\hline $78 \%-100 \%$, & 27 & 84,38 & $\begin{array}{c}\text { Sangat } \\
\text { Tinggi }\end{array}$ \\
\hline $56 \%-77 \%$ & 5 & 15,63 & Tinggi \\
\hline $40 \%-55 \%$ & 0 & 0 & Sedang \\
\hline $0 \%-39 \%$ & 0 & 0 & Rendah \\
\hline Jumlah & 23 & 100 & \\
\hline
\end{tabular}

Tabel tersebut menunjukkan bahwa hasil belajar pada tes pertemuan pertama pada siklus kedua menunjukkan peningkatan yang signifikan. Hal ini dapat dilihat pada hasil tes yang menunjukkan bahwa sebanyak 27 siswa memperoleh nilai pada kisaran 78-100, serta 5 siswa masih belum tuntas dengan nilai pada kisaran 56-77. Siswa tersebut memperoleh nilai $77,76,76,72$ dan 73 . Tetapi secara keseluruhan ketuntasan siswa pada meteri menelaah pola, struktur dan kaidah kebahasaan iklan mencapai 84,38\% siswa telah mencapai nilai diatas KKM.

Perolehan hasil belajar pada siklus 2 mengalami peningkatan yang sangat signifikan dikarenakan siswa lebih bersemangat dalam belajar kelompok, lebih aktif menjawab pertanyaan dan berkonsentrasi pada penjelasan yang telah diberikan oleh guru didalam kelas sehingga siswa memahami materi menelaah pola, struktur dan kaidah kebahasaan iklan dengan menggunakan metode pembelajaran kooperatif tipe talking stick pada proses pembelajaran. 
Dari data-data di atas dan berdasarkan hasil diskusi dengan teman sejawat, maka kegiatan penelitian dengan menggunakan metode pembelajaran kooperatif tipe talking stick pada mata pelajaran Bahasa Indonesia PKn dengan materi Iklan, Sarana komunikasi dinyatakan berhasil pada siklus Berdasarkan hasil penelitian yang dilakukan setelah menerapkan metode pembelajaran kooperatif tipe talking stick menunjukkan bahwa pembelajaran kooperatif tipe talking stick menciptakan suasana belajar yang efektif dan menyenangkan bagi siswa, walaupun terdapat kendala-kendala pada pertemuan pertama dimana dalam melakukan kegiatan tanya jawab ada beberapa siswa masih kaku, takut dan kelihatan gugup karena mereka belum terbiasa dan baru pertama kali diperkenalkan dengan metode pembelajaran kooperatif tipe talking stick, namun pada pertemuan berikutnya hal tersebut dapat diatasi. Siswa mulai terbiasa dan sangat bersemangat dalam pembelajaran. Hasil belajar siswa mengalami peningkatan sebesar $84.38 \%$.

\section{PENUTUP}

Berdasarkan hasil penelitian dan pembahasan yang telah dipaparkan oleh peneliti, maka dapat disimpulkan bahwa:

1. Metode pembelajaran talking stick dapat meningkatkan hasil belajar siswa pdi kelas VIII SMPN Singosari sebesar $84.38 \%$.

2. Dengan metode pembelajaran talking stick membuat siswa menjadi lebih bersemangat dan memperoleh nilai baik saat menjawab soal yang diberikan pada materi Bahasa Indonesia.

Oleh sebab itu dengan penerapan metode pembelajaran talking stick dapat dikembangkan untuk meningkatkan proses pembelajaran di kelas dan hasil belajar siswa.

\section{DAFTAR PUSTAKA}

Ahmad Rohani. 2004. Pengelolaan Pengajaran. Jakarta: Rineka Cipta,

Agus Suprijono. 2009 Cooperative Learning Teori dan Aplikasi PAIKEM.

Yogyakarta : Pustaka Pelajar.

Anita Lie. 2002. Cooperative Learning Mempraktikkan Cooperative

Learning di Ruang-Ruang Kelas). Jakarta: PT. Grasindo Widia Sarana

Indonesia

Arifin. 2010. Penelitian Pendidikan : Pendekatan Kuantitatif dan Kualitatif. Lilin

Persada Press.

Basrowi \& Suwandi. 2008. Memahami Penelitian Kualitatif. Jakarta : Rineka Cipta.

Bobbi De Porter. 2000. Quantum Teaching/Learning. Bandung : Kaifa.

Departemen Pendidikan Nasional, 2003. Undang-Undang Nomor 20 Tahun 2003 ,

Tentang Sistem Pendidikan Nasional, Jakarta: Depdiknas.

Departemen Pendidikan Nasional. 2006. Kurikulum Tingkat Satuan Pendidikan

(KTSP). Jakarta:Departemen Pendidikan Nasional.

John Jarolimek. 1993. Sosial studies in Elementary Education $\left(9^{\text {th }}\right.$. Ed). New

York: Macmilan Publishing.co.Ltd)

Kokom Komalasari. 2011. Pembelajaran Kontekstual Konsep dan Aplikasi.

Bandung : PT Refika Aditama

Kunandar. 2012. Langkah Mudah Penelitian Tindakan Kelas Sebagai Pengembangan Profesi Guru. Jakarta : Rajawali Pers.

Muhammad Asrori. 2012. Penelitian Tindakan Kelas. Bandung: CV Wacana Prima

Mulyasa, 2004. Implementasi Kurikulum Tingkat Satuan Pendidikan Kemandirian Guru dan Kepala 
Sekolah. Bandung: PT Remaja Rosdakarya.

Mustakim. 2007. Keefektivan Model STAD dan Jigsaw pada Pembelajaran Menyunting Siswa Kelas VIII SMP Negeri 1 Mertoyudan Kabupaten Magelang Tahun Pelajaran 2006/2007.Tesis. Semarang: Program Pascasarjana UNNES.

Peraturan Pemerintah No 19 Tahun 2005. Standar Nasional Pendidikan.

Peraturan Menteri Pendidikan Nasioanal nomor 22 tahun 2006 tentang standar isi

Rachmad Widodo. 2009. Model Pembelajaran Talking Stick. [Online] Tersedia pada http://wyw1d.wordpress.com/2009/1 1/09/model-pembelajaran-16talking-stik/(diakses tanggal 15 Juli 2017).

Ramadhani Masykur. 2011. Penerapan Metode Pembelajaran Talking Stick Untuk Meningkatkan Prestasi
Belajar Siswa Pada Pokok Bahasan Koloid

Di Kelas Xi Ipa Sma Negeri 7 Pekanbaru. Universitas Riau

Wina Sanjaya. 2006. Strategi Pembelajaran. Jakarta : Kencana Prenada Media Group.

Wina Sanjaya. 2006. Strategi Pembelajaran: Berorientasi Standar Proses Pendidikan. Jakarta: Kencana

Subana, M. Strategi Belajar Mengajar Bahasa Indonesia: Berbagai Pendekatan, +Metode Teknik, dan Media Pengajaran. Bandung: Pustaka Setia.

Sumarno, 2003. Pendidikan Kewarnegaraan. Jakarta: PT Pustaka Tiga Kelana

Sumiati \& Asra. (2009). Metode Pembelajaran. Bandung: CV Wacana Prima

Suyatno. 2009. Menjelajah Pembelajaran Inovatif .Sidoarjo : Masmedia Buana Pusaka. 